\title{
Handout Biologi Berbasis Potensi Lokal Pantai Ujong Blang untuk Siswa SMK Perairan dan Kelautan
}

\author{
Dini Annisha ${ }^{1}$, Ibrohim ${ }^{1}$, Fatchur Rochman ${ }^{1}$ \\ ${ }^{1}$ Pendidikan Biologi-Universitas Negeri Malang
}

\begin{tabular}{l} 
INFO ARTIKEL \\
\hline Riwayat Artikel: \\
Diterima: 21-05-2019 \\
Disetujui: $18-05-2020$ \\
\hline
\end{tabular}

\section{Kata kunci:}

handout;

local potential;

biology

handout;

potensi lokal;

biologi;

\begin{abstract}
ABSTRAK
Abstract: The aim of the paper is to know the validity and practicality of handout biology based on local potential of Ujong Blang beach. This study adapted the ADDIE model of research \& development. The validity of handout is known from the experts' validation score, while the practicality is known from the student's response. The results showed that the validation scores of media and material experts and practitioners had a high level of validity value (mean $>90$ ) so that was categorized as highly valid. While the test readability by students also showed highly valid level of the handout validity Based on the results, it can be concluded that the biology handout based on local potential of Ujong Blang Beach developed more feasible to implement in class XI of SMK in the learning process to improve critical thinking skills, conceptual understanding, and environmental attitude.
\end{abstract}

\begin{abstract}
Abstrak: Tujuan penelitian ini yaitu untuk mengetahui kevalidan dan kepraktisan handout biologi berbasis potensi lokal pantai Ujong Blang. Penelitian ini mengadaptasi model penelitian \& pengembangan ADDIE. Kevalidan handout diketahui dari skor validasi para ahli, sedangkan kepraktisan diketahui dari respon siswa. Hasil penelitian menunjukkan bahwa skor validasi ahli media, ahli materi dan praktisi lapangan memiliki tingkat nilai validitas tinggi (rerata $\geq 90$ ) sehingga dikategorikan sangat valid. Sementara itu, uji keterbacaan oleh siswa juga menunjukkan tingkat nilai validitas sangat valid terhadap handout. Berdasarkan hasil tersebut, maka dapat disimpulkan bahwa handout biologi berbasis potensi lokal pantai Ujong Blang yang dikembangkan layak diimplementasikan lebih lanjut kepada siswa kelas XI SMK dalam proses pembelajaran untuk meningkatkan keterampilan berpikir kritis, pemahaman konsep, dan sikap peduli lingkungan.
\end{abstract}

\author{
Alamat Korespondensi: \\ Dini Annisha \\ Pendidikan Biologi \\ Universitas Negeri Malang \\ Jalan Semarang 5 Malang \\ E-mail: diniannisha@gmail.com
}

Perubahan kurikulum yang secara berkesinambungan memiliki fungsi dan tujuan untuk meningkatkan mutu dan kualitas pendidikan agar mampu menciptakan sumber daya manusia yang memiliki kepribadian yang mandiri (BSNP, 2010) memiliki kompetensi dan keterampilan (Permendikbud, 2013) serta menerapkan metode pembelajaran yang mengacu kepada proses pembelajaran dan kinerja siswa secara sistematis (Johnson, 2015). Perkembangan pendidikan sesuai dengan tujuan pendidikan nasional diarahkan pada pengembangan Kurikulum 2013 dengan menekankan pentingnya penguatan melalui pengetahuan, sikap, dan keterampilan (Permendikbud, 2016) pada satuan pendidikan dalam jenjang dan jenis pendidikan tertentu (Permendikbud, 2013). Kurikulum pada semua jenjang dan satuan pendidikan di Indonesia juga dikembangkan berdasarkan prinsip dan tujuan untuk memanfaatkan serta melestarikan kekayaan potensi daerah dan lingkungan (Undang-Undang Nomor 20 Tahun 2003) sehingga hal ini menjadi dasar pengembangan pembelajaran berbasis potensi lokal yang disusun ke dalam materi bahan ajar yang relevan.

Terkait dengan proses pembelajaran abad 21, perubahan kurikulum seharusnya dapat dimaknai pula sebagai tujuan mengembangkan proses pembelajaran dengan menerapkan pembelajaran melaui metode atau pendekatan ilmiah pada pembelajaran Biologi (Hurd, 1997). Selain itu, memastikan bahwa kurikulum sekolah dan guru mendukung siswa belajar biologi secara bermakna (Glynn \& Muth, 1994). Prinsip dasar agar belajar bermakna terjadi yaitu (a) penggunaan materi dan bahan ajar yang relevan, (b) siswa harus memiliki konsep dasar untuk menemukan gagasan atau pengetahuan yang baru, dan (c) menghubungkan pengetahuan baru dengan struktur kognitif secara substansif atau relevan (Novak, 1993). Proses pembelajaran biologi secara bermakna dapat didukung dengan menerapkan metode pembelajaran ilmiah atau dikenal dengan pembelajaran inkuiri. 
Pembelajaran inkuiri merupakan proses belajar ilmiah yang berkaitan dengan penerapan prinsip dan metode ilmiah pada proses pembelajaran (Roll et al., 2017). Selain itu, proses pembelajaran yang disusun dalam kurikulum 2013 harus mampu memfasilitasi siswa untuk memenuhi beberapa keterampilan abad 21 yang meliputi keterampilan berpikir kritis, pemahaman konsep, serta sikap peduli lingkungan dengan menerapkan pembelajaran ilmiah. Model pembelajaran inkuiri dapat mendorong siswa untuk memiliki kemampuan berpikir yang aktif dan kritis dalam mengkonstruk pengetahuan sehingga dapat memfasilitasi siswa dalam memahami konsep yang sedang dipelajari (Arvinda et al., 2017) dan meningkatkan pemahaman konsep (Sribekti et al., 2016).Pembelajaran inkuiri juga mendorong siswa untuk memiliki kemampuan untuk bersikap rasional dalam proses pemecahan masalah (Dahlia et al., 2018) dan memfasilitasi siswa untuk memiliki sikap peduli lingkungan dengan memanfaatkan lingkungan sebagai salah satu sumber belajar (Mardikaningtyas et al., 2016).

Pemanfaatan lingkungan dapat dilaksanakan dengan memanfaatkan potensi lokal sebagai sumber belajar. Potensi lokal merupakan potensi sumber daya alam yang menjadi karakteristik dari suatu daerah. Selain itu, potensi lokal dapat dijadikan sebagai konten materi pembelajaran (Libbrecht, 2015) yang memiliki fungsi sebagai pendukung praktik guru dalam mempersiapkan proses pembelajaran (Sribekti et al., 2016). Sumber belajar akan lebih bermakna jika disusun menjadi bahan ajar (Prastowo, 2016). Bahan ajar yang memuat potensi lokal dapat merangsang kemampuan berpikir (Susilo et al., 2014) serta memberikan efek proses belajar yang kontekstual dan bermakna bagi siswa untuk menemukan hubungan antara ide abstrak dan penerapan praktis secara konseptual (Kemdikbud 2016a). Dengan demikian, potensi lokal berpeluang untuk diangkat sebagai sumber belajar yang menarik di sekolah apabila kemudian dilakukan analisis terkait kesesuaian dengan Kompetensi Inti (KI) dan Kompetensi Dasar (KD) pada Kurikulum 2013 dan disusun ke dalam bahan ajar yang kontekstual.

Fakta di lapangan hasil analisis kebutuhan pada bulan Juli 2017 di SMK Negeri 6 Kelautan dan Perairan Lhokseumawe, menyebutkan bahwa pelaksanaan proses pembelajaran selama ini belum memanfaatkan potensi lokal secara optimal oleh guru biologi. Selain itu, guru juga belum mampu memanfaatkan sumber belajar dan bahan ajar alternative yang lain untuk mendukung kegiatan belajar mengajar baik di kelas maupun diluar kelas. Minimnya pemanfaatan potensi lokal oleh guru biologi hal ini dikarenakan proses pembelajaran hanya menggunakan bahan ajar berupa buku teks yang diperoleh dari penerbit buku pemerintah sehingga proses pembelajaran hanya menggunakan metode ceramah. Kondisi ini sungguh sangat disayangkan karena SMK Negeri 6 Lhokseumawe merupakan sekolah kejuruan yang memiliki program keahlian dibidang perairan dan kelautan serta memiliki tujuan khusus yaitu memberdayakan sumber daya yang ada ada dilingkungan sekolah dengan demikian seharusnya proses pembelajaran di sekolah dapat memanfaatkan potensi lokal yaitu berupa pantai Ujong Blang.

Salah satu metode yang dapat dilakukan adalah menyesuaikan KI dan KD dengan mengintegrasikan potensi lokal pantai Ujong Blang ke dalam materi biologi sebagai sumber belajar ke dalam bahan ajar. Pengintegrasian tersebut dapat dilakukan ke dalam materi ekosistem dan perubahan lingkungan. Adapun KD yang terdapat pada materi ekosistem : (a) KD 3.2 yaitu memahami ekosistem dan interaksi yang berlangsung didalamnya dari berbagai sumber, dan (b) KD 4.2 yaitu menyajikan data berupa contoh interaksi dan jejaring makanan yang berlangsung dalam ekosistem dalam bentuk bagan, sedangkan untuk materi perubahan lingkungan terdapat pada: (a) KD 3.3 yaitu menganalisis dampak polusi terhadap perubahan lingkungan hidup dan kesehatan dan (b) 4.3 yaitu menyajikan data hasil pengamatan perubahan lingkungan dan kesehatan sebagai dampak polusi dengan ruang lingkup materi permasalahan lingkungan yaitu jenis-jenis polusi, dampak polusi, dan teknik penangganan polusi.

Uraian diatas mengindikasikan perlunya dukungan terhadap proses pembelajaran dengan mengembangkan bahan ajar alternatif yaitu berupa handout. Handout memiliki keunggulan untuk meningkatkan pemahaman siswa dalam memahami konsep ataupun fakta secara mendalam serta materi yang disusun sesuai dengan kebutuhan siswa dan bersifat kontekstual (Wulandari, et al., 2016). Handout berbasis potensi lokal pantai Ujong Blang yang akan dikembangkan dikategorikan menjadi handout yang tidak terlepas dari materi pada buku yang berarti bahwa handout yang akan dikembangkan berisi materi atau konsep baru yang belum dibahas pada buku teks yang digunakan selama proses pembelajaran (Prastowo, 2016). Handout yang dikembangkan perlu melalui tahapan validasi oleh para ahli dan siswa agar dapat diterapkan lebih lanjut dalam proses pembelajaran. Penelitian ini bertujuan untuk mengetahui kevalidan handout Biologi berbasis potensi lokal pantai Ujong Blang.

\section{METODE}

Jenis Penelitian yang diterapkan dalam penelitian ini mengadaptasi model penelitian \& pengembangan ADDIE (Branch, 2009) yang terdiri atas lima tahapan, antara lain Analyze, Design, Develop, Implement, dan Evaluate. Tahap analyze dilakukan menyebarkan angket analisis kebutuhan kepada siswa dan guru di sekolah SMK Negeri 6 Perairan dan Kelautan Lhokseumawe. Tahap design dilakukan dengan cara membuat rancangan bahan ajar berupa handout. Tahap develop dilakukan dengan cara mengembangkan handout sesuai rancangan, memvalidasi handout kepada validator, dan melakukan uji keterbacaan. Tahap implement dilakukan dengan cara menerapkan handout dalam proses pembelajaran biologi, sedangkan tahap evaluate dilakukan dengan cara mengevaluasi hasil yang diperoleh pada tiap tahapan.

Pelaksaanan penelitian ini dilakukan di SMK Negeri 6 Perairan dan Kelautan Lhokseumawe di kelas XI. Produk handout divalidasi oleh ahli materi, ahli media, dan praktisi lapangan oleh guru biologi. Setelah produk handout divalidasi selanjutnya dilakukan uji keterbacaan oleh 10 orang siswa kelas XII untuk mengetahui pendapat siswa tentang handout yang dikembangkan. Instrumen dalam pengumpulan data yaitu lembar angketvalidasi handout. Jenis data dalam penelitian ini yakni 
data kuantitatif dan kualitatif. Data kuantitatif berupa skor dari validator ahli dan siswa. Data kualitatif berupa saran, komentar yang diberikan oleh validator ahli dan siswa. Teknik analisis data hasil validasi menggunakan analisis data deskriptif dengan menggunakan rumus validasi, sedangkan untuk kriteria validitas handout dapat dilihat pada tabel 1.

Keterangan Rumus:

$$
\begin{aligned}
V-a h & =\frac{T s e}{T s h} \times 100 \% \\
V-p g & =\frac{T s e}{T s h} \times 100 \% \\
V-a u & =\frac{T s e}{T s h} \times 100 \%
\end{aligned}
$$

V-ah : Validasi ahli

V-pg : validasi pengguna (guru)

V-au : Validasi audience (siswa)

Tse : total skor penilaian

Tsh : skor maksimal yang diharapkan

Tabel 1. Kriteria Validitas Produk

\begin{tabular}{ll}
\hline Kriteria Pencapaian Nilai (Validitas) & \multicolumn{1}{c}{ Tingkat Validitas } \\
\hline $85,01-100 \%$ & Sangat valid; dapat digunakan tanpa perbaikan \\
$70,01-85,00 \%$ & Cukup valid; dapat digunakan namun perlu perbaikan kecil \\
$50,01-70,00 \%$ & Kurang valid; disarankan tidak digunakan karena perlu revisi besar \\
$01,01-50,00 \%$ & Tidak valid; tidak boleh digunakan \\
\hline
\end{tabular}

(Sumber: Akbar, 2013)

\section{HASIL}

Produk pengembangan yang dihasilkan dalam pengembangan ini yaitu handout biologi berbasis potensi lokal pantai Ujong Blang Lhokseumawe pada materi ekosistem dan perubahan lingkungan. Handout yang disusun terdiri atas tiga bagian utama yaitu halaman pendahuluan, halaman isi, dan penutup. Halaman pendahuluan terdiri atas halaman sampul, pengantar, penggunaan handout, dan capaian pembelajaran. Halaman isi terdiri atas materi ekosistem dan perubahan lingkungan serta soal evaluasi. Halaman penutup terdiri atas daftar rujukan, glosarium, dan biografi penulis. Handout juga dilengkapi dengan hasil dokumentasi pribadi serta data yang diperoleh dari Dinas Kelautan dan Perairan Kota Lhokseumawe dan berbagai referensi rujukan yang mendukung isi materi dalam handout.

\section{Validasi Ahli Media}

Data hasil validasi handout oleh ahli media menunjukkan tingkat validitas sangat valid dan data tersebut dapat dilihat pada tabel 2 .

Tabel 2. Hasil Validasi Handout oleh Ahli Media

\begin{tabular}{clcc}
\hline No. & Indikator Penilaian & Tingkat Validitas (\%) & Kategori \\
\hline 1. & Desain sampul handout & 97,5 & Sangat valid \\
2. & Desain isi handout & 97,1 & Sangat valid \\
3. & Kaidah penulisan & 100 & Sangat valid \\
4. & Kelayakan penyajian & 100 & Sangat valid \\
5. & Kepraktisan & 100 & Sangat valid \\
\hline & Rata-rata (\%) & $\mathbf{9 8 , 9}$ & Sangat valid \\
\hline
\end{tabular}

Berdasarkan pada tabel 2, skor rata-rata persentase tingkat validitas handout sebesar 98,9\% dengan kategori sangat valid. Komentar dan saran yang diberikan oleh ahli media terhadap produk handout yang dikembangkan, antara lain (1) handout yang dicetak disesuaikan dengan kaidah pembuatan buku atau bahan ajar lain, dan (2) handout di cetak dengan menggunakan cetakan ring hal ini dikarenakan agar produk handout dapat digunakan dalam jangka panjang bagi siswa, (3) secara umum handout yang disusun telah memadai kriteria sebagai bahan ajar alternatif bagi siswa. 


\section{Validasi Ahli Materi}

Aspek penilaian terhadap produk handout yang dilakukan oleh ahli materi menunjukkan hasil validasi dengan tingkat validitas sangat valid. Hasil validasi handout oleh ahli materi dapat dilihat pada tabel 3.

Tabel 3. Hasil Validasi Handout Oleh Ahli Materi

\begin{tabular}{clcc}
\hline No. & Indikator Penilaian & Tingkat Validitas (\%) & Kategori \\
\hline 1. & Bab 1 & 90 & Sangat valid \\
2. & Bab II & 90 & Sangat valid \\
\hline & Rata-rata (\%) & $\mathbf{9 0}$ & Sangat valid \\
\hline
\end{tabular}

Berdasarkan pada tabel 3, skor rata-rata persentase tingkat validitas handout sebesar 90\% dengan kategori sangat valid. Adapun selanjutnya komentar dan saran yang diberikan oleh ahli materi, yaitu (1) penambahan soal evaluasi untuk setiap bab pada materi ekosistem dan perubahan lingkungan, (2) penambahan glosarium, (3) pemilihan gambar/foto yang terdapat dalam handout perlu diperhatikan dari sisi warna, kejelasan gambar, dan keakuratannya, (4) setiap gambar/foto diberikan keterangan.

\section{Validasi Ahli Praktisi Lapangan}

Validasi produk handout yang dinilai oleh praktisi lapangan merupakan penilaian yang dilakukan oleh ahli materi. Praktisi lapangan yaitu dilakukan oleh guru Biologi di kelas XI dan hasil penilaian terhadap handout yang dilakukan menunjukkan hasil validasi dengan tingkat validitas sangat valid. Hasil validasi handout dapat dilihat pada tabel 4.

Tabel 4. Hasil Validasi Handout oleh Praktisi Lapangan

\begin{tabular}{clcc}
\hline No. & Indikator Penilaian & Tingkat Validitas (\%) & Kategori \\
\hline 1. & Bab 1 & 92,72 & Sangat valid \\
2. & Bab II & 94,54 & Sangat valid \\
\hline & Rata-rata (\%) & $\mathbf{9 3 , 6 3}$ & Sangat valid \\
\hline
\end{tabular}

Berdasarkan pada tabel 4, skor rata-rata persentase tingkat validitas handout sebesar 93,63\% dengan kategori sangat valid. komentar dan saran yang diberikan oleh praktisi lapangan, yaitu handout sudah dapat digunakan dalam proses pembelajaran.

\section{Validasi Siswa terhadap Handout}

Hasil validasi siswa terhadap handout merupakan tahapan uji keterbacaan yang dilakukan oleh siswa kelas XII sebanyak 10 orang. Berdasarkan penilaian yang diberikan handout yang dikembangkan menunjukkan hasil validasi dengan tingkat validitas sangat valid dengan skor rata-rata persentase tingkat validitas $85,06 \%$. Kemudian hasil ini menunjukkan bahwa handout praktis dan dapat digunakan untuk tahapan selanjutnya. Hasil respons siswa terhadap handout yang dikembangkan dapat dilihat pada tabel 5 .

Tabel 5. Hasil Validasi Siswa terhadap Handout

\begin{tabular}{ccc}
\hline No Siswa & Tingkat Validitas $(\%)$ & Kategori \\
\hline 1. & 85,71 & Sangat valid \\
2. & 91,42 & Sangat valid \\
3. & 81,42 & Cukup valid \\
4. & 85,71 & Sangat valid \\
5. & 82,85 & Cukup valid \\
6. & 80,00 & Cukup valid \\
7. & 91,42 & Sangat valid \\
8. & 85,71 & Sangat valid \\
9 & 81,42 & Cukup valid \\
10. & 85,00 & Cukup valid \\
\hline Rata-rata $(\%)$ & $\mathbf{8 5 , 0 6}$ & Sangat Valid \\
\hline
\end{tabular}

\section{PEMBAHASAN}

Secara umum, penggunaan bahan ajar memiliki fungsi (a) meningkatkan prestasi belajar peserta didik dan memotivasi guru untuk mendukung peserta didik dalam mencapai tujuan pembelajran (Efiong et al., 2015), (b) sebagai sumber informasi bagi siswa (Retnoningrum et al., 2016), dan (c) bahan ajar digunakan oleh guru untuk membantu siswa menemukan konsep (Kusumaningtyas et al, 2014). Handout merupakan salah satu bentuk bahan ajar cetak (Prastowo, 2016). Handout merupakan 
bahan ajar tertulis berupa materi pendukung yang disusun secara kontekstual dan memotivasi peserta didik untuk mengintegrasikan antara pemahaman kosep dan fakta (Wulandari et al., 2016). Penggunaan handout bagi peserta didik memberikan manfaat kepada mereka untuk dapat memahami konsep materi pembelajaran secara utuh karena tata bahasa handout yang sederhana serta praktis untuk digunakan saat proses pembelajaran (Nerita et al., 2006).

Handout Biologi berbasis potensi lokal pantai Ujong Blang Lhokseumawe yang dikembangkan telah melewati tahapan validasi oleh validator ahli, praktisi lapangan serta uji keterbacaan oleh 10 orang siswa. Berdasarkan hasil skor rata-rata presentase validitas yang diperoleh dapat dijabarkan sebagai berikut (1) ahli media 98,9\%, (2) ahli materi 90\%, (3) ahli praktisi lapangan 93,36\%, dan (4) siswa 85,06 \%. Hal ini menunjukkan bahwa handout yang dikembangkan memiliki tingkat validitas sangat valid dan dapat digunakan sebagai bahan ajar. Menurut Depdiknas (2008) bahan ajar yang baik yaitu tersusun secara utuh berdasarkan kompetensi yang akan dikuasai oleh siswa dalam proses pembelajaran (Depdiknas, 2008). Handout yang dikembangkan disesuaikan berdasarkan hasil analisis kebutuhan sebelumnya sehingga dalam hal ini handout digunakan pada materi ekosistem dan perubahan lingkungan.

Penyusunan handout didasarkan atas kompetensi yang terdapat pada Kompetensi Dasar yang harus dicapai oleh peserta didik (Depdiknas, 2008). Adapun langkah-langkah penyusunan handout yaitu (a) melaksanakan analaisis kurikulum terlebih dahulu, (b) menentukan judul, (c) mengumpulkan referensi yang relevan sesuai materi, (d) menggunakan jumlah kalimat yang bervariasi (e) mengevaluasi hasil tulisan, (f) melakukan perbaikan, dan (g) menggunakan sumber belajar lainnya untuk memperkaya materi dalam handout. Penyusunan dan pengembangan bahan ajar handout diutamakan pada aktivitas siswa yang mencakup pemetaan konsep melalui aktivitas belajar sehingga memungkinkan siswa untuk menerapkan dan membangaun pengetahuan tersebut (Sakraida \& Peter, 2003).

Handout merupakan bahan ajar yang kontekstual karena dapat memberikan pengalaman belajar secara langsung (Hermawati et al.,2017) kepada siswa apabila memanfaatkan lingkungan sebagai sumber belajar (Subamia et al., 2015). Lingkungan dapat dimanfaatkan sebagai sumber belajar berbasis potensi lokal untuk mendukung kegiatan pembelajaran oleh guru (Anisa et al., 2016). Pengembangan kurikulum pada jenjang satuan pendidikan dapat dikembangkan berdasarkan pemanfaatan lingkungan atau potensi daerah peserta didik dan dapat dilaksanakan pada tingkat satuan pendidikan (UU Sisdiknas No 20 tahun 2003). Dengan demikian, pengembangan kurikulum akan diseimbangkan antara kepentingan daerah dan nasional hal tersebut dianggap penting agar pengembangan kurikulum dapat menghasilkan lulusan peserta didik yang relevan dengan kebutuhan pengembangan daerah (Permendikbud 81A, 2013).

Terkait relevansi Kurikulum 2013, maka proses pembelajaran akan berjalan apabila terdapat integrasi antara bahan ajar dengan penyajian materi didalamnya untuk meningkatkan keterampilan berpikir kritis, pemahamn konsep (Kemendikbud, 2015) serta sikap peduli lingkungan (Retnoningrum et al., 2016). Penelitian dan pengembangan bahan ajar berupa handout telah banyak dilakukan oleh penelitian sebelumnya. Handout merupakan bahan ajar yang sangat menarik dan efektif bagi siswa selain itu pengembangan materi yang termuat dalam bahan ajar ini dapat didasarkan pada hasil penelitian (Hermawati et al., 2017). Selain itu bahan ajar handout dapat meningkatkan kemampuan berpikir kritis (Sribekti dkk, 2016), dapat meningkatkan pemahaman konsep siswa (Hanif et al., 2016) serta meningkatkan sikap peduli lingkungan (Mardikaningtyas et al., 2016).

Selain menggunakan bahan ajar berupa handout, kemampuan berpikir kritis, pemahaman konsep dan sikap peduli lingkungan dapat didukung dengan pembelajaran inkuiri. Beberapa penelitian menjelaskan bahwa proses pengintegrasian antara pembelajaran inkuiri dengan bahan ajar berbasis potensi lokal dapat meningkatkan kompetensi hasil belajar siswa sesuai dengan tuntutan kurikulum 2013 (Novitaningrum et al., 2014). Pembelajaran inkuiri merupakan serangkaian proses dan penilaian pedagogis untuk menemukan pengetahuan atau informasi tentang suatu fenomena yang terjadi di lingkungan melalui investigasi, pencarian, mendefinisikan masalah, merumuskan hipotesis, mengumpulkan dan menfasirkan data, dan menarik kesimpulan melalui pendekatan ilmiah (Turner et al., 2017).

\section{SIMPULAN}

Berdasarkan hasil penelitian, dapat disimpulkan bahwa handout berbasis potensi lokal pantai ujong Blang tergolong sangat valid sehingga layak untuk diimplementasikan lebih lanjut dalam proses pembelajaran Biologi pada materi ekosistem dan perubahan lingkungan di kelas XI SMA Negeri 6 Perairan dan Kelautan Lhokseumawe. Saran yang perlu diperhatikan, antara lain yaitu pelaksanaan penelitian terhadap proses pembelajaran Biologi dengan menggunakan bahan ajar handout dan diintegrasikan dengan proses pembelajaran ilmiah melalui pembelajaran inkuiri sehingga dapat diketahui pengaruhnya terhadap hasil belajar siswa yang meliputi keterampilan berpikir kritis, pemahaman konsep, dan sikap peduli lingkungan. Peneliti selanjutnya sebaiknya mempertimbangkan secara matang mengenai domain yang akan digunakan untuk membuat web untuk kenyamanan pengguna.

\section{DAFTAR RUJUKAN}

Akbar. S. (2013). Instrument Perangkat Pembelajaran. Bandung: PT Remaja Rosdakarya.

Anisa, A., Suryadarma, G. P., Wilujeng, I., \& Prasetyo, Z. K. (2016). Improving Students' Entrepreneurial Attitude Through Local Potential Pottery and Furniture of Jepara. Proceeding of $3^{\text {Rd }}$ International Conference on Research, Implementation and Education of Mathematics and Science Yogyakarta, 7-16. 
Arvinda, C. L., Ibnu, S., \& Sutrisno. (2017). Kemampuan Berpikir Kritis dan Pemahaman Konseptual dengan Inkuiri Terbimbing Dipadu Pelatihan Metakognisi pada Materi Kelarutan dan $\mathrm{K}_{\mathrm{sp}}$. Jurnal Pendidikan: Teori, Penelitian, dan Pengembangan, 2(1), 12-21.

Branch, R. M. (2009). Instructional Design: The ADDIE Approach. New York: Springer.

Badan Standar Nasional Pendidikan. 2010. Paradigma Pendidikan Nasional Abad 21. Jakarta.

Dahlia, Ibrohim, \& Mahanal S. (2018). Peningkatan Keterampilan Berpikir Kritis Siswa SMP menggunakan Perangkat Pembelajaran Berbasis Inkuiri Terbimbing dengan Sumber Belajar Hutan Wisata Baning. Jurnal Pendidikan: Teori, Penelitian, dan Pengembangan, 3(2), 188-194.

Departemen Pendidikan Nasional. (2008). Panduan Pengembangan Bahan Ajar. Jakarta: Depdiknas.

Effiong, O. E., \& Igiri, C. E. (2015). Impact of Instructional Materials in Teaching and Learning of Biology in Senior Second ary Schools in Yakurr LG A. International Letters of Social and Humanistic Sciences, 62, 27-33. https://doi.org/10.18052/www.scipress.com/ILSHS.62.27.

Glynn, S. M., \& Muth, K. D. (1994). Reading and Writing to Learn Science: Achieving Scientific Literacy. Journal of Research in Science Teaching, 31(9), 1057-1073. https://doi.org/10.1002/tea.3660310915.

Hanif., Ibrohim., \& Rohman, F. (2016). Pengembangan Perangkat Pembelajaran Biologi Terintegrasi Nilai Islam untuk Meningkatkan Pemahaman Konsep Siswa SMA. Jurnal Pendidikan: Teori, Penelitian, dan Pengembangan, 1(11), 21632171.

Hermawati, Y., Hastutui, U. S., \& Lukiati, B. (2017). Pengembangan Handout Biologi SMA Pembuatan Nata Sari Buah Nangka. Jurnal Pendidikan: Teori, Penelitian, dan Pengembangan, 2(9), 1212-1214.

Hurd, P. D. H. (1998). Scientific Literacy: New Minds for a Changing World. Journal Science Education, 82(3), 408-416. https://doi.org/10.1002.

Johnson, K. (2015). Behavioral Education in the $21^{\text {st }}$ Century. Journal of Organizational Behavior, 35(1), $135-50$. http://dx.doi.org/10.1080/01608061.2015.1036152.

Kemendikbud. (2016 a). Materi Pokok Pelatihan Implementasi Kurikulum 2013. Direktorat Pembinaan Sekolah Menengah Atas: Jakarta.

Kusumaningtias, D. A., Kurniawan, E. S., \& Ashari. (2014). Pengembangan Handout Berbasis Multiple Intelligence untuk Meningkatkan Kemampuan Berpikir Kritis Siswa Kelas X SMA Muhammadiyah Wonosobo Tahun Pelajaran 2013 / 2014. Jurnal Radiasi, 5(2), 80-84.

Libbrecht, P. (2015). Adaptations to a Learning Resource. Journal Acta Didactica Napocensia, 2(1), 67-74.

Mikits, J. (2009). The Use Classroom Handouts: United States Military Academy. New York.

Mardikaningtyas, A. D., Ibrohim., \& Suarsini, E. (2016). Pengembangan Pembelajaran Pencemaran Lingkungan Berbasis Penelitian Fitoremediasi untuk Menunjang Keterampilan Ilmiah, Sikap Peduli Lingkungan dan Motivasi Mahasiswa pada Matakuliah Dasar-Dasar Ilmu Lingkungan. Jurnal Pendidikan: Teori, Penelitian, dan Pengembangan, 1(3), 499-506.

Nerita, S., Hartati, Y. S., Maizeli, A., \& Afza, A. (2006). Practicality of Handout Based on Guided Discovery Method in Process Evaluation and Learning Outcomes of Biology. Journal of Physics: Conference Series, 1-4. https://doi.org/10.1088/17426596/1157/2/022081.

Novak. J. D. (2011). A Theory of Education: Meaningful Learning Underlines the Constructive Integration of Thingking, Feeling, and Acting Leading to Empowerment for Commitment and Responsibility. Meaningful Learning Review, 6(2), 1-14. https://doi.org/10.1080/0305764X.2017.1356267.

Novitaningrum, M., Parmin., Pamelasari, S. D. (2014). Pengembangan Handout IPA Terpadu Berbasis Inkuiri pada Tema Mata untuk Kelas IX Siswa MTs Al-Islam Sumurejo. Unnes Science Education Journal, 3(2), 542-548. https://doi.org/http://dx.doi.org/10.15294/usej.v3i2.3349.

Peraturan Menteri Pendidikan dan Kebudayaan Nomor 81 A Tahun 2013. Peraturan Menteri tentang Kerangka Dasar dan Struktur Kurikulum Sekolah Menengah Kejuruan/Madrasah Aliyah Kejuruan. Menteri Pendidikan dan Kebudayaan Republik Indonesia. Jakarta.

Peraturan Menteri Pendidikan dan Kebudayaan Nomor 22 Tahun 2016.Peraturan Menteri Tentang Standar Proses Pendidikan Dasar dan Menengah. Menteri Pendidikan dan Kebudayaan Republik Indonesia: Jakarta.

Prastowo, A. 2016.Pengembangan Bahan Ajar Tematik Edisi Kedua. Jakarta: Kencana.

Retnoningrum A., Dasna W. I., Santoso, A., (2016). Penggunaan Pendekatan Saintifik Dalam Bahan Ajar Berbantuan Multimedia Materi Konsep Larutan SMK Agribisnis Produksi Tanaman. Prosiding Semnas Pendidiikan IPA Pascasarjana UM, 1(1), 542-548.

Roll, I., Butler, D., Yee, N., Welsh, A., Perez, S., Briseno, A., Bonn, D. (2017). Understanding The Impact of Guiding Inquiry: The Relationship Between Directive Support, Student Attributes, and Transfer of Knowledge, Attitudes, and Behaviours in Inquiry Learning. Journal: Instructional Science, 46(1), 1-28. https://doi.org/10.1007/s11251-017-9437-x.

Sakraida, T. J., \& Draus, P. J. (2006). Quality Handout Development and Use. The Journal of Nursing Education, 44(7), $326-329$.

Sribekti, A., Hidayat, A., Dasar, P., \& Malang, P. N. (2016). Peningkatan Keterampilan Proses Sains dan Hasil Belajar Kognitif Siswa Kelas VII SMP Negeri 1 Selorejo Menggunakan Perangkat Pembelajaran Ekosistem. Jurnal Pendidikan: Teori, Penelitian, dan Pengembangan, 1(8), 1575-1580. 
Susilo, M. J. (2014). Analisis Potensi Sumber Belajar IPA (Biologi) SMP pada Materi Pencemaran Air di Sungai Winongo sebagai Pendukung Penerapan Kurikulum 2013 di Kabupaten Bantul. JUPEMASI-PBIO, 1(1), 176-178.

Subamia, I. D.P., Sriwahyuni, I. G. A. N., Widiasih, N. N. (2017). Pengembangan Perangkat Praktikum Berorientasi Lingkungan Penunjang Pembelajaran IPA SMP Sesuai Kurikulum 2013. JPI (Jurnal Pendidikan Indonesia), 4(2), 675-685. https://doi.org/10.23887/jpi-undiksha.v4i2.6064.

Turner, R. C., Keiffer, E. A., \& Salamo, G. J. (2017). Observing Inquiry-Based Learning Environments Using the Scholastic Inquiry Observation Instrument. International Journal of Science and Mathematics Education, 16(8),1-24. https://doi.org/10.1007/s10763-017-9843-1.

Undang-undang Sistem Pendidikan Nasional No. 20 Tahun 2003. Tentang Sistem Pendidikan Nasional. Jakarta.

Wulandari, S., Suarsini, E., \& Ibrohim. (2016). Pemanfaatan Sumber Belajar Handout Bioteknologi Lingkungan untuk Meningkatkan Pemahaman Konsep Mahasiswa S1 Universitas Negeri Malang. Jurnal Pendidikan: Teori, Penelitian, dan Pengembangan, 1(5), 881-884. 